Available Online at Website:

http://journal.uinjkt.ac.id/index.php/ahkam

Ahkam: Jurnal Ilmu Syariah, 19 (2), 2019, 229-246

https://doi.org/10.15408/ajis.v19i2.13898

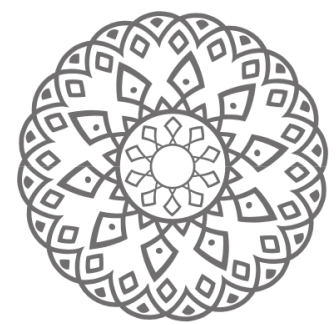

\title{
Measuring Human Rights and Islamicity of INDONESIAN ANTI-TERrorism LAW
}

\author{
Asmawi, Yayan Sopyan, Mujar Ibnu Syarif, Isnawati Rais
}

\begin{abstract}
Abstrak: Studi ini berfokus pada masalah terkait dengan sejauh mana hak asasi manusia dan keislaman (norma hukum Islam) diakomodasi dalam hukum anti-terorisme Indonesia (UU No. 5 tahun 2018). Penelitian ini menggunakan pendekatan kualitatif dengan studi dokumen. Dari hasil kajian tersebut, disimpulkan bahwa ada bagian-bagian dari UU No. 5 tahun 2018 yang memberikan potensi pelanggaran hak asasi manusia. Beberapa hal yang masih bermasalah adalah yang terkait dengan penangkapan, penahanan, hukuman mati, intersepsi atau penyadapan, dan pencabutan kewarganegaraan. Sementara itu, nilai keislaman pada UU No. 5 tahun 2018 terbuka bagi interpretasi dan reinterpretasi. Studi tentang unsur hak asasi manusia dan keislaman pada UU No. 5 tahun 2018 berkontribusi signifikan penerapan hukum pidana Islam secara substantif dalam konteks keindonesiaan, serta modernitas, yang juga berarti penerapan hukum Islam dan hak asasi manusia secara bersamaan.
\end{abstract}

Kata kunci: hukum Islam, hak asasi manusia, islamisitas, hukum anti-terorisme 
Abstract: This study focuses on the problem of the extent to which human rights and islamicity (Islamic law norms) are accommodated within Indonesian anti-terrorism law (Law No. 5 of 2018). The study uses a qualitative approach with a documentary study in data collection. The result shows that Law No. 5 of 2018 has threatened human rights in some issues. This is indicated by certain matters including arrest, detention, capital punishment, interception, and revocation of citizenship. Meanwhile, the islamicity of Law No. 5 of 2018 is open to interpretation and reinterpretation. The study of measuring human rights and islamicity of Law No. 5 of 2018 has a significant contribution to the substantive implementation of Islamic criminal law in the context of Indonesianness, as well as modernity, which also means the implementation of Islamic law and human rights at once.

Keywords: Islamic law, human rights, islamicity, anti-terrorism law 


\section{Introduction}

The general picture of the threat of extremism and terrorism in Indonesia has changed in the current decade. These changes can be seen from the emergence of new patterns in the spread of extreme understandings and the variety of terrorist attacks. The spread of violence-based extremism has targeted almost all elements of society, including young people and even children. In addition, the pattern of terrorist attacks is also more sporadic, not only targeting objects or subjects related to American interests, but also to countries that are considered its allies. Meanwhile, the perpetrators of violence began to emerge from new groups or networks, and often take action independently.

Responding to the growing challenges, since the beginning of 2016 the Indonesian Government has begun to submit revisions to Law No. 15 of 2003 on Validation of Government Regulation in lieu of Law No. 1 of 2002 on the Eradication of Terrorism Crimes. In line with the process of the revision of the law, a crucial issue emerged, namely how the efforts to deal with and eradicate terrorism can work effectively without violating human rights principles.

Terrorism crimes are serious ones committed using intentional, systematic and planned violence or threats. The acts are intended to create and spread the atmosphere of terror or fear by targeting the state's apparatus, random civilians, vital strategic objects and public (national and international) facilities. These tend to grow into a symmetric danger threatening national security and sovereignty; territorial integrity; as well as national, regional, and international peace and welfare (Gregor Bruce, 2003).

Terrorism is basically a transnational and organized crime. It has clandestine characteristics such as secret, covert and underground movement. Moreover, other characteristics are cross-country and supported by the utilization of modern technology in communication, information, transportation, and weaponry. Thus, it requires international cooperation to deal with this type of criminal activity. Additionally, terrorism is often accompanied by ideological, political, economic and other personal motives. The one that endangers the state's ideology and security are related to radicalism (ICJ, 2009). Therefore, crimes related to 
terrorism are always threatened with serious punishment by the criminal justice system of many countries around the world.

In the context of terrorism issue in Indonesia, it is crucial to discuss it in the perspective of criminal law and its relationship with human rights, and Islamic law, which, in some ways, become references in the substance of Indonesia legal system. The study of the adoption of Islamic law and human rights values in the Indonesian criminal legal system becomes important to measure the "islamicity" and the implementation of human rights in the Indonesian legal system. One of them is Law No. 5 of 2018 on the Amendment to Law No. 15 of 2003 on Validation of Government Regulation in lieu of Law No. 1 of 2002 on Eradication of Terrorism Crimes into Law (hereinafter referred to as Law No. 5 of 2018 or Anti-Terrorism Law). In addition, for the Indonesian criminal legal system, in this case of Law No. 5 of 2018, This is also to see the adoption of the two values in the context of criminal legal reform. The question is that to what extent that Islamic law and human rights are considered in the Indonesian criminal justice; and whether the law No. 5 of 2018 is in line with Islamic criminal law and human rights.

Furthermore, it can be said that the most serious challenge of Muslim people-amid the frenetic efforts of the application of Islamic Shari'a and human rights at once-is to clarify matters related to Islamic criminal law. An in-depth study of Islamic criminal law and how to implement both Islamic law and human rights values in the Indonesian criminal legal system, as is represented by Law No. 5 of 2018. Therefore, this paper focuses on how human rights and islamicity have been accommodated by Indonesia Anti-terrorism law as represented by Law No. 5 of 2018.

\section{Defining Terrorism}

According to James M. Lutz and Brenda J. Lutz (2005), the absence of an international legal definition of terrorism does not necessarily imply abolishing a legal definition of terrorism. Until today, there is no universally accepted definition of terrorism. Each country defines terrorism based on their respective national beliefs and interests. The formulation of terrorism's criteria inflicts a problem of multiinterpretation of state stakeholders. 
Terrorism is initially limited and local, with selected objects, and occurs within a context of low-intensity conflict. In general, terrorism is closely related to a country's internal stability. However, today, terrorism has a broad dimension and links to various aspect of life. Terrorism has occurred beyond national boundaries and is no longer regarded as a low-intensity conflict. In the current context, terrorism has no longer targeted political life, as was before. The target has been expanded into destroying pillars of human life, such as economic affairs, humanity, culture, and civilization. Terrorism is one of the eight types of transnational crime (Ewit Soetriadi, 2008) along with war crime, genocide and aggression. Terrorism is considered as a threat to the world's culture and humanity. Therefore, fighting against terrorism is a must in all ways, including by legal and military approaches, and involving various parties such as legal enforcement officers.

Law No. 5 of 2018 states that terrorism is an action committed using violence or a threat of violence to create an atmosphere of terror or widespread fears, which lead to casualties, damages, destructions of vital and strategic objects with political, ideological and security disrupting motives (Article 1 Number 2). The previous law did not contain such a definition. The addition to the new law is intended to strengthen the role of Indonesian authorities to carry out pre-emptive or early prevention to terrorism. This is confirmed by Article $13 \mathrm{~A}$ and $15 \mathrm{~B}$, stating that it is possible for the police to take actions to written propaganda and hate speech, which is considered as the initial stages of terrorism. Hate speech, in this case, constitutes an expression of intolerance. Terrorism is the peak of this intolerance.

\section{Combating Terrorism and Respecting Human Rights}

Terrorism is real and has direct impacts of human rights issues such as devastating the right to life, liberty and physical integrity of the victims. In addition to these individual costs, terrorism can destabilize governments, undermine civil society, jeopardize peace and security, and threaten social and economic development. All of these also have a real impact on human rights.

Terrorism is very destructive to individuals' basic rights so that it is presumed as a crime against humanity. Moreover, individual 
security is a basic human right. The protection of individuals' rights is, accordingly, a fundamental obligation of government. The state, therefore, must ensure the protection of their citizens' human rights and others, by taking positive measures to protect them from the threat of terrorist actions and bring the perpetrators to justice (David P. Stewart, 2018).

In recent years, however, the measures adopted by states to counter terrorism have often posed serious challenges to human rights. Some states have used violence measures and other ill-treatments to terrorism. Meanwhile, legal and practical safeguards are available to prevent torture, such as regular and independent monitoring of detention centres. However, these have often been disregarded ( Daniel Byman, 2018). Some states have transferred the convicting terrorists to countries where they can face real risks of torture, which is, in fact, a serious human rights abuse. Thereby, this violates the international legal obligation of non-refoulment. The independence of judicature has been undermined, while the use of a special court to bring civilians to justice has an impact on the effectiveness of regular judicature system. Repressive measures are used to stifle conscience of human rights activists, journalists, minorities, indigenous groups, and civil society.

Material and financial resources, which are normally allocated in social and development programmes, have been diverted to the security sector that affected the economic, social and cultural rights of people (Jessica Almqvist, 2005). The violence practices in responding to terrorism issues, particularly when taken together, have a corrosive effect on the rule of law, good governance and human rights. They are also counterproductive to national and international efforts to combat terrorism.

Human rights are universal values and legal guarantees that protect individuals and groups from the negligence and abusive acts of state, especially from state agents, which violate the fundamental freedom and rights of the people. The spectrum of human rights includes the honour and protection of civil rights, cultures, economy, politics and social and development rights. Human rights as a universal value mean that it inherently belongs to all human, which are interdependent and indivisible. 
Terrorism aims at destructing the value of human rights, democracy, and the rule of law. Specifically, the attacked values lie at the heart of the United Nation Charter and other international values. Other attacked values include the rules of governing armed conflict, the protection of civilians, tolerance among people and nations, and peaceful conflict resolutions.

International and regional human rights laws make clear that state have both rights and duty to protect individuals under their jurisdiction from terrorist attacks. This stems from the general duty of states to protect individuals under the jurisdiction against the interference in the freedom of human rights. More specifically, those rights include the right to life and the right to security. In the International Covenant on Civil and Political Rights (ICCPR) describes the rights to life as "the supreme right", because, without an effective guarantee, all human rights values will be meaningless. As such, states have an obligation to protect individuals' rights to life. The derogation of this right is not permitted, even in times of public emergency. The protection of this right includes the obligation of the state to take all appropriate and necessary steps to safeguard the lives of their people.

As a part of this obligation, the states must put in place effective criminal justice and law enforcement system, such as preventing and investigating offences; ensuring that the suspected criminals are prosecuted; providing effective victims recovery; and take other necessary steps to prevent the offences to recurrence. In addition, the international and regional human rights law acknowledges that, in certain circumstances, states have an obligation to take operational or preventive steps to protect individuals whose life is known to be threatened by or at risks of others' criminal acts, including terrorism.

\section{Human Rights Dimension of the Indonesian Anti-Terrorism Law: Islamic Law Perspective}

In Indonesia, Todung Mulya Lubis (2018) criticizes Law No. 5 of 2018. According to Lubis, there is a number of articles that allow unlimited authorities to the law enforcers. These articles endanger the democracy, which in Indonesia is still growing. Also, there are still some rules in that law that support the implementation of retroactive 
principles. This is contrary to the principle of legality. In terms of law enforcement efforts, there is a need to maintain its compatibility with the universally applicable legal principles. If the contrary happens, then it legitimizes the arbitrariness which, in turn, hinders and undermines the democratic process in the country.

Article 12A, 12B, and 13A of Law No. 5 of 2008 widen the types of terrorist actions. This, indirectly, shows "excessive criminalization" to the suspects. Moreover, Article 12B (3) potentially suppresses freedom of expression. To prevent counter-terrorism efforts from committing violations against human rights, accountability is needed in dealing with terrorism cases. Furthermore, Law No. 5 of 2018 can anticipate the possibility of involving children and teenagers in terrorism. Terrorists, who involve children and teenagers in their actions, are subjected to a more severe punishment, which is $1 / 3$ heavier than the common violations.

In 2004, the Indonesian Council of Ulama issued a fatwa (Islamic legal opinion) on terrorism. According to the MUI, crimes on terrorism induce heavier destruction in many aspects, including casualties, destruction of public facilities, security and economic instabilities. Furthermore, MUI sees that there has been misunderstanding in the notion of jihad and terrorism among Muslim communities. Therefore, MUI insists that terrorism is not jihad. Terrorism is a crime against humanity ad civilization, which poses a serious threat to national sovereignty, world peace and security and people's welfare. MUI considers terrorism as an organized and transnational crime with a significant impact. Terrorism does not differentiate its objects. MUI, further, explains that terrorism has several characteristics, such as 1) it poses destruction (ifsad), anarchy, and chaos; 2) it aims at spreading fears and destroying people; 3) committed without rules and limits. By considering the teaching in Islamic law, MUI treats terrorism as the hirabah (war) offences.

Jihâd, according to MUI, is all efforts and willingness to bear any difficulties in fighting against any aggression of enemies in all ways. This is known as al-qitâl or al-harb. Also, jihâd is interpreted by the Council as any genuine and sustained efforts to maintain and elevate the religion of Allah (li ilẩi kalimatillah). From that definition and interpretation, jihâd is clearly different from terrorism. MUI explains 
that the characteristics of jihâd as follow: 1) bringing improvement or being reformative (islâb ) even in war; 2) aiming to uphold the religion of Allah or defend the rights of those who are oppressed (nusrat almazlùm), and (iii) being carried out in accordance with Sharia rules (Islamic law) and has clear objectives.

Concerning the fatwa, Nima Karimi (2017) argues that counterterrorism fatwa has not been that effective due to its weak argument. Fatwa has a persuasive characteristic. At the same time, there some other thesis showing that some verses in the Quran impress violence and, therefore, justify terrorism. MUI fatwa that proposes counter-terrorism is less persuasive compared to the ones endorsing violence. However, The MUI Fatwa, in this case, has challenged the belief of Islamists terrorists and made them reconsider their previous interpretation of the Quran.

A closer look at Law No. 5 of 2018 reveals that there some parts of the law that pose serious threats to human rights. These include in the area of arrest, detention, capital punishment, interception, and revocation of citizenship. Efforts to revise the law should consider that the law aims to strengthen the state and its society in encountering terrorism threats. This should not be counterproductive with the possible violation against human rights in the law.

First possible violation against human rights in the law No. 5 of 2018 is in the provision of arrest, especially in the period of arrest. Normatively, the arrest is an action to temporary limit the suspects' freedom if evidence for further investigation of prosecution is sufficient, or during the trial process. According to Article 28 of Law No. 15 of 2003, the duration of arrest is limited to a maximum of 7x 24 hours. Related to this, the Government conducted a study, and the result is that it proposes a maximum arrest limit to thirty days. After going through debates in the Parliament, it was finally agreed that the duration of the arrest is limited to a maximum of fourteen days, and it could be extended to a maximum of seven days, as is stipulated by Law No. 5 of 2018.

This paper argues for the need of the law enforcers to uphold the value of human rights in dealing with the suspected terrorists since their arrest. This is, in fact, has not been confirmed by Law Article 28 of Law No. 15 of 2003 concerning Anti-Terrorism. Meanwhile, 
according to Article 19 of the Indonesian Criminal Code, an arrest can be made at a maximum one day or 1 x 24 hours. Moreover, in the proposed revision of the Criminal Code, it is mentioned that the arrest duration is maximum of $3 \times 24$ hours for certain location with difficult geographical arrests.

Some arguments proposed by the government regarding the need to extend the arrest period is that the investigators will be able to uncover the terrorist networks in the regional, national and international scopes. More than that, the arrest of suspected terrorists often faces complexity with regards to the location, available transportation. Moreover, delving and investigating terrorist networks and obtaining information from the suspects are also challenging and need times. Those factors underlie the reason for the need of more arresting periods in the new law.

In Islamic criminal law, the arrest duration is in the domain of tazir punishment, where the government's authority works perfectly ('Âmir, 1990). Theoretically, the concept of ta'zir consists of criminal and penal sanctions that are beyond the domain of hudud and qisas/diyat. As to penal sanction, ta'zir is defined as a sentence or punishment whose crime is not determined by the Shariah, and therefore is not included in had or qisas/ diyat violation ('Audah, 1990). Thus, a person who is arrested as a suspect is not subjected to qisas/diyat punishment. This means the arrest is included in $t a^{\prime} z i r$ which depends on the provision of the government or authority.

From the perspective of Human Rights, there are numbers of potential threats in the proposal of the long period of arrest. First, there is a possible practice of tortures and enforced disappearances. Second, the suspected terrorists can lose their access to outside world, including access to their family and legal aids. Third, there is a possibility that the arrest is undisclosed and without the knowledge of the suspected terrorists' family. Four, there is a possibility that the authority uses unprofessional policy. The arrest should be based on accurate intelligent information. The last, the access of families and lawyers to the suspected terrorists is closed by the authority, including access to information about the arrest, its time, locations, and names of the suspect. Due to the complexity of dealing with suspected terrorists, there is a need to propose $3 \times 24$ hours for the arrest period. 
Moreover, efforts to increase the arrest period (fourteen days plus seven days) is contrary to international human rights law instrument. The International Covenant on Civil and Political Rights (ICCPR), which was ratified by the Indonesian Law No. 12 of 2005, stipulates that the arrested suspects must be immediately taken before a court or an authority that has the power to exercise judicial actions, including to examine the validity of the arrests. Article 9 of the ICCPR outlines that every individual can only be arrested for maximum of 48 hours or two days. Other than that, Principle 15 of the Body of Principles for the Protection of All Persons from Any Form of Detention states that although there are exceptions contained in Principle 16 Paragraph (4) and Principle 18 Paragraph (3), communication of detainees with outside environment, especially with family or his lawyer, may not be delayed for more than one day.

In the view of Islamic law, the arrest of a suspect is in the domain of siyâsah syar'iyyah or Islamic political system ('Utwah, 1993). This means that the government may determine a policy or take action based on Islamic legal values regarding governance system applicable in that country (Khallâf, 1998). The principle of siyâsah syar'iyyah, on the one hand, ensures that the flexibility of the government policy and actions is truly implemented. On the other hand, it implies that the rationalization carried out by the government may appear to be the implementation of maslahah (public interests).

Another issue that may threaten the principle of human rights in detention is the body that is given the detention authority. Normatively, the detention authority is given to investigators, prosecutors, or judges, as is determined by the law. In the case of terrorism, the detention authority is given to the investigators. Article 25 of Law No. 5 of 2018 determines that the detention period for suspects is 120 days. After that, this can be extended, if needed, to 60 days and then to maximum 20 days. In total, the maximum detention is 200 days. Article 25 of Law No. 15 of 2003 states that the detention period of terrorist suspects is at maximum six months or 180 days. Several regulations on suspected terrorist detention period are lex specialis of the Indonesian Criminal Procedural Law, which states that the maximum detention period is 60 days with a gradual pattern. A careful examination of two laws on terrorism, there is a difference in the detention periods for suspected 
terrorists. Law No 5 of 2018 gives maximum period longer than the total duration.

However, Law No. 5 of 2018 implements a gradation pattern for the objective needs of the detention. Two-hundred-day period of detention is different from the one that is stipulated by the International human rights law. In this regards, the government argues that detention with longer periods is needed to be able to obtain valid information about the root of terrorism cases. So far, the investigation process of terrorism cases is hampered by the limited detention period, so the investigators fail to obtain information.

The above detention is pre-trial detention. Such detention, however, is not in line with the stipulation in the Indonesian Criminal Procedure Code. In this regards, one principle is violated, which is the need to bring the suspects before the court and let them go through the court process. The International Covenant on Civil and Political Rights (ICCPR) ensures the rights of the suspects and convicts to be adjudicated at a reasonable period or to be released. This is important because the practice may abuse individual civil rights as well as the rights to privacy. A reasonable imprisonment punishment is important to protect individual rights during the pre-trial period. ICCPR, and other regional human rights instruments, such as American Convention and European Convention on Human Rights, asserting that the arrested or detained individuals have rights to be brought before the court or to be released. The committee of human rights determines that the six-month period (180 days) is too long for someone to be detained before the trial. ICCPR and the Body Principles guarantee that the rights of the suspects or convicts are to be protected. In this case, they should undergo a reasonable period of trial or be released. Based on this provision, the state should be responsible for ensuring that all trial process is undertaken without delay. The UN Human Rights Committee insists that the state cannot avoid its responsibility if the delay in trial happens. In this case, the suspect should demand the rights to be tried immediately.

To avoid excessive detention for terrorist suspects, there is a need to revise several anti-terrorism laws and regulations. The idea is to propose a detention period that is in accordance with the Indonesian and international legal standards. First, in the investigation, the 
investigators are allowed to arrest the suspects for maximum ten days. Second, the detention periods as is mentioned can be extended by the general attorney for maximum twenty days. Third, the prosecution purpose, the detention is given by the prosecutor is valid for sixty days. Four, the detention duration for prosecution can be extended by the district court with maximum thirty days.

In the perspective of Islamic law, the detention of the suspected terrorists in the open for legal reasoning (ijtihad). During the time of the Prophet Muhammad, he arrested someone, a Bani Nadir Jew, who committed embezzlement of Huyyay ibn Akhtab's property. After obtaining sufficient evidence, the Prophet order Zubair ibn 'Awwam to carry out the detention (Jauziyyah, 2002). In the current context, some Islamic scholars use this case as the basic argument in siyâsah syar'iyyah or political Islam, as is mentioned above.

Another human rights issue within the Anti-Terrorism Law is regarding the rules of interception. According to Law No. 5 of 2018, Article 31, the interception can be done without a court warrant. The procedure of interception, however, should be reported to the investigator. This is set back from the previous law (Law No 15 of 2013). If the provision in the new law is maintained, then, there would be a possible excessive use of power and authority in the interception. This is because no authorities, other than the investigators, monitor and preside the interception process.

Martin Scheinen. The UN Special Rapporteur on the Promotion and Protection of Human Rights and Basic Freedoms in Combating Terrorism asserts that the use of interception methods has a number of side effects. These side effects include: 1) surveillance creates fears on the freedom of expression and individuals' privacy; 2) there has been a limitation in the rights to associate and do public gatherings; 3 ) the freedom of movement (move from one place to another) is limited; 2) justice is potentially violated or fair legal process might be abused.

In practice, interception is often used by governments around the world to maintain national security, especially to prevent and eradicate terrorism. The practice of interception takes various form, such as the use of Stop and Search Powers; the use of biometric technology and a centralized identification system model; the surveillance of suspicious 
people on the list (watch-list monitoring), and the control over individual switching activities. Responding to this, Martin Scheinen proposes five principles of legal protection in the terrorism eradication attempts, namely: 1) the principle of minimal intervention (minimal intrusiveness); 2) the principle of limited personal data using; 3) the principle of supervision and regulation of accessing private data; 4) the principle of openness and honesty; and 5) the principle of effective modernization (in Efendi, 2003).

In Islamic law, interception is fundamentally forbidden because it harms personal privacy, as is explained in the Quran and Hadith. Spying (tajassus) is a forbidden deed and lead to great sin in the eye of God (Q.S.49:12). Along with that, the Prophet Muhammad emphasized that spying (tajassus) brings detrimental excess to be personal and social life, and as a consequence ruins Islamic brotherhood (as reported by al-Bukhârî and Muslim). Interception constitutes spying, and both have similar principles and consequences as being a forbidden and sinful deed. However, something forbidden $y$ is permitted in an emergency or if needed. Islamic legal maxims (Al-qawā'id al-fiqhīyah) prescribe as follow: 1) al-darûrât tubîh alma $\underline{h} \hat{u} r a \hat{t}$ or necessities render the prohibited permitted; 2) al-hâjjah

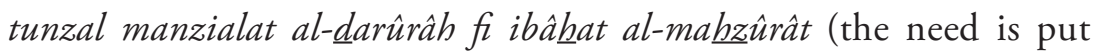
in the emergency position in order to permit something forbidden). Therefore, interception with certain conditions is possible and permissible.

The last crucial issue in Law No. 5 of 2018 is related to capital punishment. The government, through Law No. 5 of 2018, shows a strong commitment to dealing with terrorism. The provision of capital punishment is in Article 6 and Article 14 of the law. Article 14 declares that capital punishment is for the leaders or intellectual actors of terrorism. The anti-capital punishment faction (abolitionist faction) reject capital punishment, as is stated by Law No. 5 of 2018. This rejection is based on several arguments such as; first, and capital punishment is against the Indonesian constitution and legislation as well as international human rights law. Law No, 39 of 1999 on Human Rights stipulates that the right to life is a fundamental human right that cannot be reduced and derogated under any circumstances. Indonesia has also ratified 
the International Covenant on Civil and Political Rights (ICCPR) through Law No. 12 of 2005. Particularly, Article 6 Paragraph (1) affirms that the right to live in an inherent right to each individual, regardless of differences in citizenship status.

Second, capital punishment is considered cruel and inhumane. International human rights law declares that capital punishment is cruel and inhumane and degrading an individual's rights. Therefore, the capital punishment contradicts with 1945 Constitution, Human Rights Law, ICCPR, as well as the Convention Against Torture (CAT), which has been ratified in Indonesia by Law No. 5 of 1998. Third, the weakness in criminal justice system that may cause mispenalizing. In many cases, mispenalizing often happens in criminal justice system as a result of unfair trial processes. In the case of death penalty, mispenalizing is irreversible. Fourth, the deterrent effect of the death penalty is mere myth. According to conventional views, the death penalty is deemed necessary to prevent someone from committing a crime. In contrast, a comprehensive survey conducted by the United Nations in 1988 and 1996 found that there was no scientific evidence indicating that capital punishment has a greater deterrent effect than long life imprisonment.

Fifth, capital punishment poses a hardship experience for the convicted family. In this case, the family becomes co-victim of capital punishment. In the context of terrorism eradication, the use of capital punishment becomes counterproductive because it can trigger radicalization among the convicts' family, which in turn leads to subsequent terrorist actions. Sixth, capital punishment contradicts the reform in the criminal justice system. Capital punishment tends to emphasize a retributive aspect. Meanwhile, the paradigm of criminal justice system has moved towards restorative justice. In the discussion of the new Indonesian Criminal Procedure Code in the parliament, it has been agreed that capital punishment would no longer be a basic punishment.

In the perspective of Islamic law, terrorism in its various forms has caused the loss of properties and live, as well as created insecurity among the people. This shows the serious impact of terrorism. MUI, in its fatwa, argues that terrorism has covered the elements of hirabah crime. MUI further maintains that the Qur'an verse (Q.S. 
al-Mầidah/5:33) stipulates the hirâbah crime and its sanction (MUI, 2006). The same Qur'anic verse underlines the capital punishment for terrorism ( hirâbah) actors. This is reasonable considering that terrorism constitutes a crime against humanity and civilization, and bring serious threats to states' sovereignty, national security, world peace, and the welfare of society. Terrorism appears to be organized and transnational crime. Moreover, it is classified as an extraordinary crime that does not discriminate its targets. This becomes the reason for the need for capital punishment for the terrorists.

\section{Conclusion}

This paper concludes that Law No. 5 of 2018 threatens human rights in some issues. These include the arrest, detention, capital punishment, interception, and revocation of citizenship. The islamicity of Law No. 5 of 2018 is open to interpretation and reinterpretation. Those issues correlate with Islamic law, especially in the application of maslaha (public interests) as well as siyasah shar'iyyah (political Islam). In human rights perspectives, the above issues are problematic. Consequently, Law No 5 of 2018 needs to be reviewed comprehensively; and a revision needs to be considered accordingly. In this case, the islamicity of the Law may be reinterpreted in line with contemporary human rights measures. The result of this new measurement contributes to the implementation of Islamic criminal law in the context of Indonesianness and modernity. Substantively, this also implies the implementation of Islamic law and human rights at once.

\section{References}

Almqvist, Jessica. (2005). "Rethinking Security and Human Rights in the Struggle against Terrorism”. ESIL Forum. 27 May 2005.

Âmir, 'Abd al-'Azîz. (1990). al-Tázîr fi al-Syarî‘ah al-Islâmiyyah. Beirut: Dâr alFikr al-'Arabiy, p. 83-90

'Audah, 'Abd al-Qâdir. (1990). al-Tasyrî̀ al-Jinâìy al-Islâmîy. Beirut: Dâr al-Kâtib al-Arabîy, p. 685-690.

Bruce, Gregor. "Definition of Terrorism: Social and Political Effects", Journal of Military and Veterans' Health, p. 26-30.

Efendi, Johari. (2003). RUU Terorisme: Antara Upaya Penanggulangan Terorisme 
dan Perlindungan HAM, Jakarta: Indonesia Civil Society Against Violent Extremism (C-Save), p. 2.

International Commission of Jurists. (2009). Assessing Damage, Urging Action: Report of the Eminent Jurists Panel on Terrorism, Counter-terrorism and Human Rights. Geneva: International Commission of Jurists, p. 22

Jauziyyah, Ibn Qayyim. (2002). al-Turuq al-Hikmiyyah fi al-Siyâsah al-Syar'iyyah. Jeddah: Dâr 'Âlam al-Fawầid, p. 14.

Karimi, Nima. (2017). Fatwas Against Terrorism and Terrorist Organization: An Examination of A Potential Counter-Terrorism Tool. Ontario, Canada: University of Waterloo, p. 98.

Khallâf, 'Abd al-Wahhâb. (1988). al-Siyâsah al-Syar'iyyah fi al-Syu'ûn al-Dustûriyyah wa al-Khârijizyah wa al-Mâliyyah. Kairo: Dâr al-Qalam, p. 20.

Lubis, Todung Mulya. (2018). “ Mengawal Transisi Penegakan Hukum dan Demokrasi (Fenomena Permasalahan Penegakan Hukum Anti-Terorisme di Indonesia) “, dalam Rudhy Suharto, (et.al.) (eds.), Terorisme, Perang Global dan Masa Depan Demokrasi, Depok: Matapena, hlm. 3

Lutz, James M., Brenda J. Lutz. (2005). Global Terrorism. New York: Routledge, p. 8-14.

Majelis Ulama Indonesia. (2006). Fatwa MUI tentang Terorisme. Jakarta: Badan Informsi Publik-Departemen Komunikasi dan Informasi, 2006, p. 1-11.

Office of the United Nations High Commissioner for Human Rights, Human Rights, Terrorism and Counter-terrorism, Fact Sheet No. 32, p. 1.

OSCE/ODIHR. (2007). Countering Terrorism, Protecting Human Rights: A Manual. Warsaawa, Poland: OSCE/ODIHR, p. 37

Sudrajat. (2004). " Kebijakan dan Langkah-Langkah Antisipatif dan Proaktif dalam Menghadapi Ancaman Terorisme ". in BPHN, Majalah Hukum Nasional, No. 2, p. 32.

Schinkel, Willem, "On the Concept of Terrorism", Journal of Contemporary Political Theory, 8, 2, 176-198. www.palgrave-journals.com/cpt/.

Setara Institute. (2016). Pernyataan Pers Setara Institute tentang Catatan Kritis atas Draft RUU tentang Perubahan atas UU No. 15 Tahun 2003 tentang Pemberantasan Tindak Pidana Terorisme, 3 Maret 2016.

Soetriadi, Ewit. (2008). Kebijakan Penanggulangan Tindak Pidana Terorisme dengan Hukum Pidana. Jakarta: Universitas Indonesia, hlm. 78.

Stewart, David P. (2018). Terrorism and Human Rights: The Perspective of International Law. Washington, DC: The Middle East Institute, p. 12.

Winarta, Frans H. "Terorisme itu Kejahatan Luar Biasa ", dalam dalam Rudhy Suharto, (et.al.) (eds.). (2004). Terorisme, Perang Global dan Masa Depan Demokrasi, Depok: Matapena, p. 26. 
Byman, Daniel. (2018). Terrorism and the Threat to Democracy. Foreign Policy at Brooking, p. 6.

'Utwah, 'Abd al-Âl Aḥmad. (1993). al-Madkhal ilâ al-Siyâsah al-Syar'iyyah. Riyadh: Jâmi'ah Muhammad ibn Su'ûd al-Islâmiyyah, p. 30.

Asmawi, Yayan Sopyan, Mujar Ibnu Syarif, Isnawati Rais UIN Syarif Hidayatullah Jakarta, Indonesia

E-mail: asmawi@uinjkt.ac.id 